Institute of $\mathbf{F}_{\text {ood and }} \mathbf{A}_{\text {gricultural }} \mathbf{S}_{\text {ciences }}$

\title{
Cotton Cultural Practices and Fertility Management ${ }^{1}$
}

\section{David Wright, Jim Marois and Jim Rich²}

Preparation for planting cotton can be done by strip-tilling rows 4 to 6 weeks before planting into a cover crop or old crop residue to warm the soil.

Strip-till planting can also be made a one-pass operation by running rows and planting at the same time. Bedding in the fall and knocking off beds to plant into moist soils in the spring has become more popular with conservation tillage. Tilling and bedding rows 4 to 6 weeks ahead of planting, followed by knocking off tops of beds to plant into moist and warmer soils, is a widely accepted practice on non-irrigated fields. Bedding with early planting may be the best way of ensuring stands in non-irrigated fields. Where irrigation is available, neither bedding nor subsoiling is as critical; however, ripping rows ahead of strip tillage or bedding usually results in warmer soils, which may be critical to reduce stand loss due to seedling disease in early planted cotton. Most soils in Florida have a natural compaction layer 6 to 14 inches deep and must be subsoiled or follow perennial grass sods that leave root channels through the compaction layer to allow cotton roots to grow through. Soil moisture is usually adequate for planting in late March to early April; it dries out in late April to May.

\section{Stands and Plant Population}

The desired cotton plant population is $2-3$ plants per foot of row in 36-inch-wide rows. To get this population, plant 4-5 seeds per foot of row. If environmental stress factors are high (drought, wet, cold), increase the seeding rate. If stands are too thick, disease and insect problems will be increased. For quick emergence, high-quality cotton seed should be planted into moist seedbeds, using depth bands or down pressure springs to control seeding depth. Seed depth should be from $1 / 2$ to 1 inch deep, but not over 1 inch because of increased chance of seedling disease and poor stand establishment from crusting. Plant when there is good soil moisture and when the overnight lows are expected to be $62^{\circ} \mathrm{F}$ or higher for 5 days following planting. When planted at this time, seedlings should emerge in 5 to 7 days and a stand established in 8 to 11 days. Growers can decide whether or not a stand is adequate within 2 weeks after planting. The first stage of germination is water uptake. Cotton seed is notorious for being dehydrated and slow to absorb water. Sandy soils do not hold water well, conduct water poorly and dry out more rapidly than other soils. These factors contribute to

1. This document is SS-AGR-194, a publication of the Agronomy Department, Florida Cooperative Extension Service, Institute of Food and Agricultural Sciences, University of Florida. Publication date: September 2003. Please visit the EDIS website at http://edis.ifas.ufl.edu.

2. David Wright, Professor, Agronomy Department, North Florida Research and Education Center--Quincy, FL; Jim Marois, Professor, Plant Pathology Department, North Florida Research and Education Center--Quincy, FL; Jim Rich, Professor, Entomology and Nematology Department, North Florida Research and Education Center--Quincy, FL. Florida Cooperative Extension Service, Institute of Food and Agricultural Sciences, University of Florida, Gainesville, FL 32610.

The use of trade names in this publication is solely for the purpose of providing specific information. UF/IFAS does not guarantee or warranty the products named, and references to them in this publication does not signify our approval to the exclusion of other products of suitable composition.

The Institute of Food and Agricultural Sciences is an equal opportunity/affirmative action employer authorized to provide research, educational information and other services only to individuals and institutions that function without regard to race, color, sex, age, handicap, or national origin. For information on obtaining other extension publications, contact your county Cooperative Extension Service office. Florida Cooperative Extension Service/Institute of Food and Agricultural Sciences/University of Florida/Christine Taylor Waddill, Dean. 
poor cotton stands frequently obtained in Florida's sandy soils. However, data shows that plant densities from 1 to 5 plants/ft of row make little difference in yield (Table 1) and if stands are as low as 1 plant/ft, good yields can still be expected.

Temperature is also critical to successful seed germination. Once a cotton seed begins to absorb water, temperature is very important to survival and development of the plant. Specifically, soil temperature less than $50^{\circ} \mathrm{F}$ causes chilling injury. A plant may be killed if exposed to temperatures of $50^{\circ} \mathrm{F}$ or lower after absorbing water, or it may result in weak plants, delayed maturity and reduced yields. Because of this susceptibility, planting should be delayed until soil temperatures are at least $65^{\circ} \mathrm{F}$ and preferably higher. The optimum soil temperature for seed germination is near $85^{\circ} \mathrm{F}$.

Skip-row planting was used under a farm program that allowed farmers to grow base acres of cotton, which resulted in an increased yield on a planted acre basis and also increased air movement through the canopy to help in reduce boll rot. Yields from 2 rows planted and 1 skip had a $25 \%$ increase in yield on a planted acre basis, while 2 rows planted and 2 rows skipped had a $40 \%$ higher yield than solid planted cotton. However, keep in mind that more land is required in skip-row plantings. Also, there is less advantage to skip row planting on soils that tend to produce excessive stalk growth than on other types of soils. Much of the problem with rank cotton can be overcome with timely applications of mepiquat chloride (Pix, etc.) and N management. Herbicides and irrigation will still be needed on the entire land area and taxes or land rent have to be paid on the entire area. Florida data has shown a slight economic advantage to skip row cotton with the $2: 1$ skip being the most economical and other skip patterns not much different from the full plant system. Skip-row requires more management, since planters, sprayers, and other equipment have to be modified to adapt to skip row patterns.

Cotton can be double-cropped successfully behind wheat for grain. However, if there is a problem with getting stands (dry weather, packing rains, insects, etc.) and planting is done in late May or early June, it is often mid to late June before the poor stand problem is recognized; by then it is too late to replant without sacrificing yields. Under irrigated conditions, cotton stands are usually not a problem and very good yields have been obtained with late May and early June plantings.

The advantages of 30-36" cotton over 40" row widths have been examined over the past 25 years in numerous studies from California to the Southeast. Extensive trials have shown that 30-36" rows are comparable in cost to a 40" row system. Other studies have shown that with appropriate modifications of production practices, 30-36" cotton out-yields cotton planted in wider rows. Most of the producers in the Southeast and Florida plant in 36" rows to accommodate other crops being grown simultaneously so that equipment does not have to be changed back and forth during the growing season.

Although it is true that narrowing rows in fields that produce small plants improves yields by intercepting more sunlight, water, and nutrients, narrow-row cotton on vigorous soils may also have yield advantages over wider row cotton. However, adjustments to seeding rate, fertilization, and the use of growth regulators such as Pix may be needed.

\section{Fertilization}

Of the row crops normally grown in Florida, cotton has the slowest early growth and the lowest nutrient uptake for the first 60 days of growth, but this increases rapidly at squaring. Therefore, fertilization needs should be timed to provide adequate nutrition to the young cotton plants at the rapid development stage. As with other crops requiring $\mathrm{N}$ fertilization, $\mathrm{N}$ management is critical to ensure adequate vegetative growth without applying excessively high rates that cause rank growth and, if applied after the third week of bloom, poorer yields. Boll rot and hard lock are caused by disease organisms and are increased with shading, high humidity and temperature and poor insect control which are associated with high $\mathrm{N}$ applications.

Nitrogen needs for cotton under different soil types and crop rotations are shown in Table 2 and may vary with soil type and cropping history. Our data show that $\mathrm{N}$ applications made after the third week of bloom result in lower yields than when $\mathrm{N}$ is 
applied earlier, and that $\mathrm{N}$ applied after the third week often has little or no effect. Therefore, late applications are detrimental to yield and costly to apply. This suggests that even if the plant has a $\mathrm{N}$ deficiency late in the season and the plant has a good fruit load, no additional N should be applied. Four years of Florida data show that the optimum time to apply $\mathrm{N}$ is at first square followed closely by at planting applications on heavier soils. It is probably not necessary to make more than one sidedress application of $\mathrm{N}$ on heavy soils, while two applications may be made on sandy soils (at squaring and at first bloom). (Table 2)

Petiole testing for adequate $\mathrm{N}$ and $\mathrm{K}$ levels in plant tissue can be done through private laboratories or with fairly inexpensive kits. This can help to determine how and when $\mathrm{N}$ and $\mathrm{K}$ should be applied on these fields in another year.

If cotton is planted on sandy soils, $\mathrm{K}$ applications may be split between at-plant (1/3 or less) and squaring to early bloom (2/3). Where petiole K levels have been followed using this practice, no $\mathrm{K}$ deficiencies have been noted. Table 3 shows why sidedress applications of nutrients may be beneficial during high rainfall years on sandy soils. Less than $10 \%$ of the $\mathrm{N}, \mathrm{P}$, and $\mathrm{K}$ were taken up during the first 60 days, while more than $80 \%$ of the nutrients were taken up during the next 60 day period.

High rates of $\mathrm{P}$ in the starter fertilizer are not necessary unless soil tests are low and call for high rates of $\mathrm{P}$. Since $\mathrm{P}$ moves little in the soil, all of the $\mathrm{P}$ may be applied at planting.

Some fields of cotton have leaf diseases and defoliate early under high rainfall conditions. Research shows that low $\mathrm{K}$ results in disease incidence and inadequate amounts of $\mathrm{K}$ are in the leaves to fill the bolls. Sidedressing K near the row and applying amounts called for from soil tests is crucial on sandy soils that are low in K.

\section{Starter or Row-Applied Fertilizer}

Fertilizers are most efficiently used when applied near the row where most of the roots occur. Liquid or complete dry granular fertilizer may be applied at planting near the row, and some data suggest that rates may be reduced 25 to $30 \%$ when row-applied as compared with broadcast applications. Starter or row-applied fertilizer may be more critical on infertile, cold, and droughty soils. Starter N on sandy soils has resulted in increased yields, while no yield increase was noted for starter $\mathrm{N}$ on heavy soils. Many producers apply a mixture of $28-0-0-5$ and $10-34-0$ in a dribble beside the row or a 2" x 2" placement. These mixtures may be composed of 3 or 4 parts of 28-0-0-5 to 1 part 10-34-0, up to $1: 1$ mixtures on soils needing more $\mathrm{P}$. If liquid $\mathrm{N}$ is dribbled to the side of the row, distance away from the seed should be 2 " for every $20 \mathrm{lbs}$ N/A. Complete dry granular fertilizers such as 3-9-18 or 5-10-15 have been applied over the row at planting or immediately after planting at 500 lbs/A with good results. Micronutrients can also be applied at planting if granular fertilizers are applied in-row. Sulfur is generally required on soils where the clay layer is 12 " or deeper. The $\mathrm{S}$ needs may be met partially in the starter fertilizer (1/3 or less) followed by a sidedress application along with $\mathrm{N}$ at the square-early bloom period. Applying $\mathrm{S}$ at $30 \mathrm{lbs} / \mathrm{A}$ has resulted in as much as a bale increase in lint on sandy soils.

\section{Strip-Till Cotton}

Management practices for strip-till cotton are essentially the same as for conventional plantings. Rows can be stripped off several weeks prior to planting to warm up the soil in the strip for early planting. The cover crop can be killed with materials having a low rate of residual material (such as Roundup or Gramoxone) to inhibit new weed seedling development. If 2,4-D or residual cotton herbicides are used to help kill weeds and reduce regrowth, at least 4 weeks is necessary between killing the cover crop and planting; otherwise seedling injury can occur. If moisture and soil temperature are adequate, a single pass of a strip-till rig with planters results in good stands and yield. Volunteer peanuts and other hard-to-control weeds have been removed by a second pass with the strip-till rig if 3-4 weeks have passed between the initial pass and planting and if the seedbed is generally smoother.

Killing cover crops or weeds several weeks ahead of planting reduces cutworm and soil insect 
problems and allows soil moisture to remain available to the new cotton seedlings. Other production practices are much the same as conventional farming, except that hooded or shielded sprayers are used instead of cultivation. If no cultivation is done, there are usually fewer weeds and fewer "flushes" of weeds.

If nematodes are a problem in strip-tilled fields, it may be advisable to plant in row middles the following year if cotton follows cotton, because nematode numbers may remain many times higher in-row compared with row middles. This is more of a problem if there has not been a killing frost and cotton roots survive the winter. However, three years of research has shown a 33\% higher yield by planting in row middles of reniform-infested cotton as compared to planting again in-row.

Many years of research on cotton has shown that yields are as high or higher from strip-tillage when compared with conventional plantings. Strip-tillage also has the advantage of preventing sand-blasting on young plants, as well as moisture conservation and erosion benefits. Herbicide tolerance with new genetic-technology cotton has made the transition to conservation tillage easier.

\section{Ultra Narrow Row Cotton}

Ultra narrow row cotton (UNRC) is cotton grown in rows 10 inches wide or less. This concept has been applied to harvesting hardlock cotton, as well as providing potentially higher yields on sandy soils that normally will not canopy over row middles in 36-inch rows. Stripper harvesters cost less than cotton pickers and are less expensive to maintain. High land rent and production cost increases have made profit margins slim for cotton growers. UNRC offers potential advantages over wide row cotton in the following ways:

- only 3 to 4 bolls are needed per plant to obtain two bale cotton,

- cotton may be planted on poorer soils and take advantage of entire soil area for water, nutrients, and light,
- lower costs for harvesting cotton with a stripper as compared to a picker, requires less time to make a crop (as little as two weeks of bloom as compared to eight weeks for wide row cotton),

- less year-end insect control, because of the week or two shorter season required to produce the crop,

- cotton may be planted later or be double-cropped and still have high yield potential because of the shorter fruiting period needed.

Many growers are looking at UNRC for fields that have typically not produced profitable yields. These may be sandy fields or fields that have had a previous crop grown on it. However, if cotton is to be grown in narrow rows, herbicide-resistant varieties should be considered. Late emerging weeds may be controlled by over-the-top applications of materials like Roundup or Staple according to the label. Many times canopy closure is accomplished after 35 days in narrow row cotton and may require 55 days or more in wide row cotton. This shading effect has a tremendous effect on weed control, and makes a big difference in utilization of water, nutrients, and light. However, adequate moisture at planting with a drill and stand establishment have been a serious concern.

Normally, stand densities should range between 80,000 and 120,000 plants per acre to keep weeds from becoming a problem and to maintain small stalks. Small stalks are desirable to keep strippers from pulling limbs and plant parts from the cotton plant to keep bark levels low in the seed cotton. There is a concern about thrips and plant bugs where Temik or other insecticides cannot be applied on narrow rows unless special hoppers are attached to planters and drills. However, materials like Gaucho and Orthene may be used as seed treatments to help in early-season insect control. Other concerns are keeping cotton short and small to keep "barky" cotton to a minimum. Cotton can be kept short by setting fruit early, having a good stand, and using of growth regulators as needed. Generally UNRC is shorter than wide-row cotton but will still require an early application of a growth regulator to help keep height down in wet years. Because plants are shorter 
and have a slightly briefer growing season, total node number is usually lower than for wide-row cotton, UNRC having about 15 nodes as compared to 20 or so for wide-row cotton. It is hoped that the shorter plants will result in less boll rot, which usually occurs on the larger bolls at the bottom of the canopy.

Our research has shown that when stacked varieties (Roundup Ready and $\mathrm{Bt}$ ) were used togther, yields increased by as much as 200 pounds of lint per acre. In UNRC, two applications of Roundup at a low rate provided excellent weed control, followed by desiccation and stripping. Nitrogen should be applied at squaring to early bloom with no late applications to allow cotton to cut out for early defoliation and opening. Our research has shown a large yield advantage to UNRC production as compared to wide row cotton. Much of this yield difference is due to harvesting hardlock with the stripper (Table 4). No-till planting of UNR cotton is often difficult due to dry, hard soil conditions in May when cotton is normally planted. A prepared seedbed with a drill often produces better drilled results. Many questions remain on varieties, planting dates and how to best use UNRC without getting discounts for quality. Most gins have discounted stripper cotton before being graded. This has discouraged grower adoption of UNR cotton production. 
Table 1. Effect of cotton plant density on plant growth characteristics and yield (Information from D\&PL).

\begin{tabular}{||l|c|c|c|c|}
\hline \hline \multicolumn{5}{|c|}{ Cotton Plant Density } \\
\hline & \multicolumn{4}{|c|}{ Plants/ft row } \\
\hline Item & 1 & 3 & 5 & LSD .05 \\
\hline Height & 47 & 46 & 46 & N.S. \\
\hline Node \# & 25.1 & 24.2 & 23.6 & 0.2 \\
\hline FP Bolls \% & 31 & 46 & 53 & 3.8 \\
\hline Veg Bolls & 36 & 16 & 9 & 3.4 \\
\hline Lint Yield Ibs/A & 1149 & 1198 & 1115 & N.S. \\
\hline \hline
\end{tabular}

Table 2. Nitrogen needs of a cotton crop on different soil types following different crops.

\begin{tabular}{|c|c|c|c|c|}
\hline \multirow[t]{4}{*}{ Previous Crop } & \multicolumn{4}{|c|}{ Soil Type } \\
\hline & \multicolumn{2}{|c|}{ Clay $12 "$ deep or more } & \multicolumn{2}{|c|}{ Clay 8-12" deep } \\
\hline & Starter & Sidedress & Starter & Sidedress \\
\hline & \multicolumn{4}{|c|}{ Ibs N/A } \\
\hline Cotton & 20 & $100-120$ & 20 & $60-90$ \\
\hline Peanuts or Soybeans & $10-20$ & $80-100$ & 0 & $60-70$ \\
\hline $\begin{array}{l}\text { *Double Crop with } \\
\text { Wheat }\end{array}$ & $10-20$ & $80-100$ & $10-20$ & $60-70$ \\
\hline
\end{tabular}

Table 3. Total nutrient uptake by cotton during the growing season. ${ }^{a}$

\begin{tabular}{|c|c|c|c|c|}
\hline \multirow[t]{2}{*}{ Nutrient } & \multicolumn{4}{|c|}{ Days after planting } \\
\hline & 60 & \multicolumn{2}{|c|}{$\mathrm{lb} s / \mathrm{A}$} & 135 \\
\hline Nitrogen & 10 & 55 & 108 & 119 \\
\hline Phosphorus & 1 & 7 & 15 & 7 \\
\hline Potassium & 7 & 47 & 98 & 112 \\
\hline \multicolumn{5}{|c|}{$\begin{array}{l}\text { a Sabbe, W.E. and L.J. Zelinski 1990. Plant analysis as an } \\
\text { aid in fertilizing cotton. In R.L. Westerman (ed.). Soil testing } \\
\text { and Plant Analysis. 3rd edition. Soil Sci. Soc. Am. Inc. } \\
\text { Madison, WI. Pp. 469-493. }\end{array}$} \\
\hline
\end{tabular}


Table 4. Tillage comparison of UNRC to 36" Row Cotton at NFREC, FL.

\begin{tabular}{|c|ccc|}
\hline \hline $\begin{array}{c}\text { Row width } \\
\text { (inch) }\end{array}$ & Conventional & $\begin{array}{c}\text { Tillage } \\
\text { Conservation } \\
\text { lbs lint/A }\end{array}$ & Average \\
\hline 7 & 1150 & 1002 & 1076 \\
36 & 776 & 795 & 786 \\
Avg. & 963 & 899 & 931 \\
\hline \hline
\end{tabular}

